\title{
Prevalence and Risk Factors of Benign Prostatic Hyperplasia among Men Attending Naturopathic Health Centers in the Adenta Municipality \\ Augustina Tetteh*
}

Department of Naturopathy and Holistic Medicine, Nyarkotey College of Holistic Medicine

DOI: N/A

| Received: 02.09.2020 | Accepted: 11.10.2020 | Published: 05.12.2020

*Corresponding author: Augustina Tetteh

\section{Abstract}

Background: Many epidemiological studies have demonstrated a high prevalence of benign prostatic hyperplasia $(\mathrm{BPH})$ and allopathic management in different parts of the world but little is known in the area of naturopathy. The objective of the present study was to establish the prevalence and risk factors of BPH in naturopathic health centers from Adenta Municipality, Ghana. Methods: The study performed a cross-sectional study design to estimate the prevalence of benign prostatic hyperplasia in naturopathic health centers among respondents aged thirty (30) and above years old. The study also adopted convenience and purposive sampling in selecting its 30 respondents. Results: The prostatic-specific antigen (PSA) of all the respondents was high. The associated risk factors were age, financial challenges, hypertension, diabetes, hypercholesterolemia, history of prostate and hormonal disturbance, red meat consumption, smoking, alcohol abuse and stress ( $p$-value $<0.005)$ respectively. Majority adopted naturopathic methods of treatment and saw improvement in the symptoms. Naturopathic approaches utilized were diet and clinical nutrition, homeopathy, botanical medicine. Conclusion: The prevalence of BPH is still high among all age groups from the young to old. This is partly due to financial challenges, financial challenges and stress, family history of prostate, high arterial hypertension, diabetes, prostate disturbances, increased cholesterol, red meat consumption, smoking and alcohol abuse. Naturopathic method of treatment can be used to manage BPH.

Key words: Naturopathic, epidemiological studies, Hyperplasia.

Copyright () 2020 The Author(s): This is an open-access article distributed under the terms of the Creative Commons Attribution 4.0 International License (CC BY-NC 4.0) which permits unrestricted use, distribution, and reproduction in any medium for non-commercial use provided the original author and source are credited.

\section{GENERAL INTRODUCTION Background to the Study}

Benign Prostatic Hyperplasia (BPH) is a noncancerous increase in size of the prostate gland [1]. The disease process has a prevalence of approximately $50-60 \%$ among the sixty year olds, and $80-90 \%$ among 70-year-old men and above [2]. Prostate enlargement among Ghanaian men between the ages of 40 and 70 is reported to be $64 \%$ [3]. The symptoms of $\mathrm{BPH}$ are mostly lower urinary tract symptoms (LUTS) and these include waking up to urinate at night, urgency, frequency, incontinence of urine and inability to empty the bladder completely and weak urine stream [4].

Benign prostatic hyperplasia although not deadly, it is accompanied by serious morbidities such as depression and decreased health related quality of life such as sleep, psychological conditions, activities in daily life, and sexual activities [5].
There are several allopathic approaches available to treat BPH: drug therapy, psychotherapy. However, the treatment options that are available come with many problems [6]. For instance, alpha blockers help relax bladder neck muscles and muscle fibers in the prostate, making urination easier [7]. However, according to Lepor [8], alpha blockers — which include alfuzosin, doxazosin, tamsulosin and silodosin - usually work quickly in men with relatively small prostates but side effects might include dizziness, fainting, headaches, lightheadedness, low blood pressure and condition in which the semen goes back into the bladder instead of out the tip of the penis (retrograde ejaculation).

For these reasons, many resort to alternative medicines or decide to remain untreated to avoid 
negative side effects and dependency of pharmacotherapy [9].

One of the largest alternative medicine modalities is that of naturopathy, which combines nutritional, herbal and other complementary practices to treat such conditions [10]. According to Louise et al., [11], naturopathic medicine is a primary health care profession that functions to promote health, prevent, diagnose and treat disease. Moreover, the intent of a naturopathic doctor (N.D.) is to stimulate the selfhealing capacities of the individual by using a number of therapeutic modalities that include botanical medicines, clinical nutrition/diet counseling, nutritional supplements, homeopathy, physical medicine (physiotherapy, hydrotherapy, manipulation) and psychologic counseling [12]. Also, naturopathic medicine is practiced as either a complement or an alternative to conventional medicine [13].

\section{Problem Statement}

The commonest disease of the prostate of men around the world is Benign Prostatic Hyperplasia [14]. In 2012, the Korle-bu Teaching Hospital (KBTH) reported that $30 \%$ of cases seen with genitourinary conditions were BPH Annual Report, 2012. This increased to $79 \%$ between a period of 5years (from 2012 to 2017). This shows a significant increase in the number of BPH cases. At the Komfo Anokye Teaching Hospital, $50 \%$ of patients seen at the urology clinic have BPH Annual Report, 2016. The records show how there had been significant increase from 2010 to 2016.

Most researches done in Ghana have focused on the allopathic methods of treatment, awareness, prevalence and screening of BPH among elderly men from 50 and above [3, 15]. But not much is known about BPH under forty years of age and more especially other methods including the naturopathic approaches to treatment in Ghana. This therefore create a theory gap for identification.

\section{Objectives of the Study}

The main objectives of this study was to assess the prevalence and risk factors of benign prostatic hyperplasia among men aged thirty and above attending naturopathic health centers in the Adenta Municipality.

The Specific objectives were:

1. To determine the prevalence of benign prostatic hyperplasia among men aged thirty and above attending naturopathic health centers in the Adenta Municipality.

2. To identify the risk factors of benign prostatic hyperplasia among men aged thirty and above attending naturopathic health centers in the study area.

3. To determine the various naturopathic care methods for patients with benign prostatic hyperplasia
4. To identify the challenges of naturopathic care by benign prostatic hyperplasia among men aged thirty and above attending naturopathic health centers in the study area.

5. To suggest ways of mitigating the challenges in adopting naturopathic methods in managing benign prostatic hyperplasia in the study area.

\section{Research Questions}

1. What is the prevalence of benign prostatic hyperplasia among men aged thirty and above attending naturopathic health centers in the Adenta Municipality?

2. What are the risk factors of benign prostatic hyperplasia among men aged thirty and above attending naturopathic health centers in the Adenta Municipality?

3. What are the naturopathic care methods for managing benign prostatic hyperplasia among men aged thirty and above attending naturopathic health centers in the study area?

4. What challenges do patients with benign prostatic hyperplasia face in using naturopathic methods of treatment?

5. How can the challenges of naturopathic care methods in managing BPH in the Adenta Municipal be mitigated?

\section{Significance of the Study}

Benign prostatic hyperplasia is common among the blacks than the whites [3]. Incidence of BPH is on the increase. Prostate cancer was diagnosed in 63 patients out of $241(26.1 \%)$. Benign prostatic hyperplasia was diagnosed in $172(71.4 \%)$ patients and the remaining $6(2.48 \%)$ had chronic inflammation. Despite the high prevalence of $\mathrm{BPH}$ and the socioeconomic burden related to its treatment, the alternative methods of treating the condition has not given much attention.

Although research works have been done on the complementary therapies methods of treating patients with $\mathrm{BPH}$ in the western world and in other nearby countries like Uganda, Ethiopia Nigeria and others [16], yet little research work has been done in Ghana. By exploring holistic methods of management and treatment will help fight the condition, the findings would help policy makers and stakeholders to prepare specific solutions to improve on the holistic natural methods of treating BPH patients. The findings may contribute towards policy decisions and help in developing integrated interventions to turn around the unmet needs of patients with BPH in the study area and Ghana as a whole. In addition, findings from this study would serve as a primary source of information for future studies regarding holistic methods of treating $\mathrm{BPH}$. 


\section{Scope of the Study}

Geographically, the study covered one Municipal, Adenta Municipality situated in the East of Accra, Ghana's regional capital. The contextual scope of the study however focused on assessing the various approaches of naturopathic care adopted by the men twenty years and above with erectile dysfunction attending naturopathic centers in the municipal.

It specifically examined the methods of naturopathy, determinants of erectile dysfunctions, challenges of adopting the different naturopathic methods and suggested solutions to the challenges mitigating the use of those methods. The study is a cross sectional survey which covered a period one year (2019-2020).

\section{Organization of the Study}

The study has been organized into five chapters. Chapter one deals with the background to the study and statement of the problem, research objectives, research questions, significance of the study, scope and organization of the study. Chapter Two of the study covered the review. With this, past works pertaining to the topic under study, definition of key concepts, conceptualization of the topic and identification of gaps in the approaches and previous literature are examined. Chapter Three focused on the methodology used to conduct the study. This specifically includes the research design, sampling procedures, data collection and data analysis. Chapter Four discusses and presents the findings of the study. Chapter Five contains the summary of findings, suggestions and recommendations that will inform policy as well as a conclusion to the study.

\section{Limitations of the study}

A limitation of the study is the systematic bias that the researcher did not or could not control and which could inappropriately affect the results [17]. The study was limited because of the following reasons assigned below: Inadequate resources could not permit the researcher to consider quite sizable number of municipalities and as well as high number of respondents that will enable the work to be highly representative.
Similarly, due to the sensitive nature of the condition, some respondents were demanding financial inducements before responding to the questions posed which hindered the study. Also, the time for the research was limited considering the broad nature of the topic itself. It is worthy of note that the concept erectile dysfunction and naturopathy care is broad which demands a longer period of time to study.

\section{LITERATURE REVIEW Brief Introduction}

This chapter is centered on the conceptual frameworks of benign prostatic hyperplasia (BPH) and naturopathic approaches. Issues in this chapter include the explanations of relevant concepts and characters of $\mathrm{BPH}$, naturopathy and its application in management of BPH among men aged thirty and above in Adenta municipality of Ghana, the various risk factors of BPH and naturopathic methods and the challenges in adopting these approaches. The chapter will also zoom it onto the types of naturopathic approaches appropriate for the study.

\section{Conceptual issues of benign prostatic hyperplasia and naturopathy}

Anatomy of the Prostate Gland and Its Functions

The prostate is an accessory genital gland with the size and shape of a chestnut. The gland is located in the pelvis, inferior to the bladder, where it surrounds the prostatic part of the urethra. It consists of 30 to 50 tubuloalveolar glands arranged in three concentric layers: aninner mucosal layer, an intermediate sub mucosal layer, and a peripheral layer containing the main prostatic glands [18, 19].

The main function of the prostate gland is to store part of seminal fluid and assist ejaculation during sexual activity. During ejaculation, the smooth muscles in the prostate help the semen. The slightly alkaline fluid produced by the prostate makes up $25 \%$ of seminal fluid and allows sperm motility and viability. The vaginal tract is acidic therefore the alkalinity of the semen neutralizes the environment to allow the sperm to stay viable. A major constituent of prostatic secretion is prostate specific antigen (PSA), along with citrate $(18.7 \mathrm{mg} / \mathrm{ml})$, zinc $(488 \mu \mathrm{g} / \mathrm{ml})$, spermine $(243 \mathrm{mg} / \mathrm{ml})$ and cholesterol $(78 \mathrm{mg} / \mathrm{ml})$ [18]. 


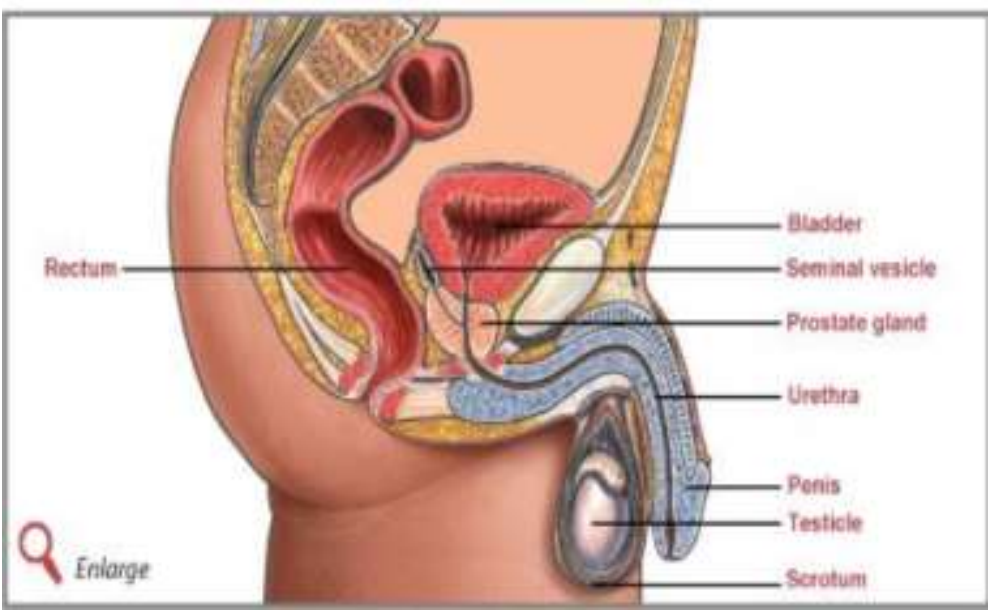

Fig-1: Diagram showing the prostate gland

\section{Benign Prostatic Hyperplasia}

Benign prostatic hyperplasia is used to indicate that a patient has an enlarged prostate or that the patient has urinary symptoms that are believed to be the result of bladder outlet obstruction by the prostate. This can lead to a host of many complications such as urinary retention, urinary hesitancy, and frequent urination as well as increased risk of urinary tract infections [20]. Prostate-specific antigen (PSA) is a protein made by cells in the prostate gland (both normal cells and cancer cells). PSA is mostly found in semen, but a small amount is also found in blood. BPH is one possible cause of a high PSA level. Inflammation of the prostate, or prostatitis, is another common cause of a high PSA level. The PSA level in blood is measured in units called nanograms per milliliter (ng/mL). According to American Cancer Society guideline for the early detection of prostate cancer [21], a person with $(\mathrm{PSA}>4.0 \mathrm{ng} / \mathrm{ml}$ ) is said to have $\mathrm{BPH}$.

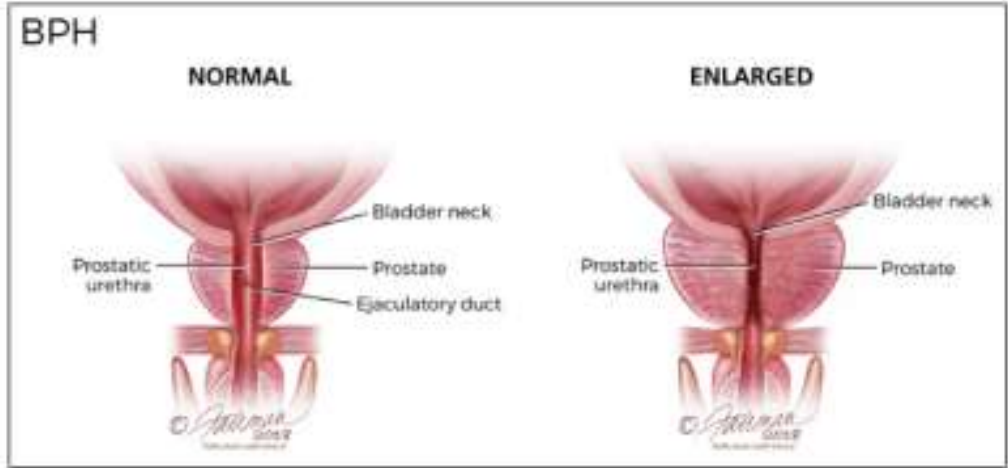

Fig-2: Diagram showing normal and enlarged Prostate

\section{Prevalence}

Prevalence is the number of disease cases present in a particular population at a given time. It is the proportion of persons in a population who have a particular disease or attribute at a specified point in time [22].

\section{Risk Factors}

According to Lopez et al., [23], risk factor are things that increases a person's chances of developing a disease. For example, cigarette smoking is a risk factor for lung cancer. The more risk factors you have, and the greater the degree of each risk factor, the higher your chance of developing a disease.

\section{Naturopathy}

Naturopathic medicine is a system that uses natural remedies to help the body heal itself. It embraces many therapies, including herbs, massage, acupuncture, exercise, and nutritional counseling [10].

\section{Risk factors of BPH among men}

Theories point to dihydrotestosterone (DHT), a male hormone that plays a role in prostate development and growth. Some research has shown that, even when testosterone levels in the blood start to fall, high levels of DHT still build up in the prostate. This may push prostate cells to continue to grow. Scientists have noted that men who do not produce DHT do not develop BPH [24].

Prostate gland enlargement rarely causes signs and symptoms in men younger than age 40. About onethird of men experience moderate to severe symptoms by age 60 , and about half do so by age 80 . Although the 
exact cause is unknown, changes in male sex hormones that come with aging may be a factor. Throughout their lives, men produce both testosterone, a male hormone, and small amounts of estrogen, a female hormone. As men age, the amount of active testosterone in the blood lowers, leaving a higher share of estrogen. Studies have suggested that BPH may happen because the higher share of estrogen in the prostate adds to the activity of substances that start prostate cells to grow [25].

Smoking and coffee consumption as a risk factor. It has been accepted that plasma steroid hormone levels are affected by cigarette smoking [26]. Higher testosterone levels are observed for smokers in previous studies, which tends to be associated with higher intraprostatic dihydrotestosterone (DHT) levels, a key factor for BPH. Nicotine in cigarettes has been shown to lead to increased DTH level in the prostate and increased sympathetic nervous system activity, contributing greatly to $\mathrm{BPH}$ [27].

According to Patel \& Parsons [28], a family history of prostate problems or abnormalities with men testicles may raise their risk of BPH. Genetics are also thought to play a role in BPH. Men with a first-degree relative such as a father or brother who has been affected by BPH are more likely to develop the condition than men who do not have a first-degree relative who has been affected [29].

Obese men with diabetes and/or high blood pressure for long durations are at an increased risk of $\mathrm{BPH}$ [30]. Men with hypertension are more likely to have large prostate volume than men without hypertension [31]. A diet high in saturated fats, red meat and refined sugars can worsen the symptoms of BPH. High cholesterol and type-2 diabetes may increase the risks of $\mathrm{BPH}$ [32].

\section{Naturopathic approaches of BPH}

The naturopathic approaches to $\mathrm{BPH}$ may include but limited to; diet and clinical nutrition, homeopathy, traditional Chinese medicine, acupuncture, botanical medicine/herbal, lifestyle modification and treatment counselling.

\section{Diet and Clinical Nutrition}

Pygeum (African plum extract). It has been shown to contain a wide range of fatty acids, alcohols, and sterols such as beta-sitosterol that have an antioxidant and anti-inflammatory effect on the urogenital tract. Some studies indicate that consuming between 100 and $200 \mathrm{mg}$ of pygeum extract daily may help reduce $\mathrm{BPH}$ symptoms [33].

Cucurbita pepo (pumpkin seed). According to Dreikorn [33], pumpkin seeds contain beta-sitosterol, a compound similar to cholesterol and found in some plants. Preliminary studies have shown that betasitosterol may improve urine flow and reduce the amount of urine left in the bladder after urination. Some studies recommend taking $10 \mathrm{~g}$ of pumpkin seed extract daily for BPH symptoms.

Lycopene. It is a naturally occurring pigment found in many fruits and vegetables. Studies found that it may help slow the progression of BPH. Tomatoes are the richest source of lycopene available to most people. But a few other fruits and vegetables contain lower levels of this antioxidant. Usually, the deeper pink or red the fruit or vegetable is in color, the higher its lycopene content. Other sources of lycopene include: papaya, pink grapefruit, watermelon, guava, carrots, red bell peppers, apricots, red cabbage [34].

According to Goodarzi et al., [35], Zinc supplements may help to reduce urinary symptoms that are linked to an enlarged prostate. Chronic zinc deficiencies have been shown to potentially increase the likelihood of developing BPH. Taking zinc supplements, or increasing dietary intake of zinc may help reduce urinary symptoms associated with an enlarged prostate. Zinc is found in poultry, seafood, and several types of seeds and nuts, such as sesame and pumpkin.

Green tea has a lot of antioxidants called catechins that have been shown to enhance the immune system and potentially slow the progression of prostate enlargement [36].

According to Ranjan et al., [37], there are several types of foods and nutrients can reduce or $\mathrm{BPH}$ and its associated symptoms including:

- fiber-rich foods, such as whole grains, legumes, beans, and dark, leafy greens

- fruits and vegetables rich in antioxidants, usually dark red, yellow, and orange varieties

- foods rich in zinc, such as eggs, most types of seafood, and nuts

- $\quad$ products that contain phytoestrogens, such as soy foods, chickpeas, alfalfa, and fava beans

- foods rich in omega-3 fatty acids, including most fish and some nuts and seeds, such as hemp and chia.

\section{Botanical Medicine}

Saw palmetto is one the most studied and popular herbal supplements used to treat BPH. Several studies have linked saw palmetto to reduced $\mathrm{BPH}$ symptoms. This is most likely because it inhibits the production of testosterone and reduces the size of the inner lining of the prostate [38].

Cernilton Some people use herbal supplements made from rye-grass pollen to treat $\mathrm{BPH}$ symptoms [34]. These troublesome symptoms may include being unable to empty the bladder fully and the need to urination frequently at nighttime. Under the brand name cernilton, rye-grass pollen is included in the formula of 
several registered pharmaceutical supplements targeted at easing symptoms of BPH. Some studies indicate it may help reduce the overall size of the prostate [39].

Babassu or orbignya speciosa is a species of palm tree native to Brazil. Several indigenous Brazilian tribes and communities use the dried or ground kernels from the tree to treat urogenital symptoms and conditions. Oil from babassu nuts has also been shown to inhibit the production of testosterone, while other parts of the nut contain compounds with antiinflammatory and antioxidant properties [40].

Stinging nettle contains similar antioxidant and anti-inflammatory compounds as pygeum and saw palmetto. Nettle root is sometimes used in combination with saw palmetto [41].

\section{Traditional Chinese Medicine}

Zi-shen pill (zsp) contains a mixture of three plants, including chinese cinnamon. Researchers have shown that rats given the $\mathrm{Zi}$-Shen formula have reduced rates of $\mathrm{BPH}[42]$.

\section{Homeopathy}

According to Weinstein [43], the following remedies are effective for the treatment of benign Prostatic Hyperplasia (BPH) including:

Chimaphilla umbellate remedy is often helpful when the prostate is enlarged, with urine retention and frequent urging. The person may have the feeling that a ball is lodged in the pelvic floor, or experience pressure, swelling, and soreness that are worse when sitting down.

Pulsatilla. Prostate problems with discomfort after urination and pains that extend to the pelvis or into the bladder (often worse when the man is lying on his back) suggest a need for this remedy. There may also be a bland, thick, yellow discharge from the penis. Pulsatilla is usually suited to emotional individuals who want a lot of affection and feel best in open air.

Apis mellifica. Stinging pain during urination that is worse when the final drops are passing is a strong indication for this remedy. Discomfort may also involve the bladder. The prostate area is swollen and very sensitive to touch. The person may feel worse from heat and from being in warm rooms, with improvement from being out in open air or from cool bathing.

Clematis remedy is often indicated when swelling of the prostate seems to have narrowed or tightened the urinary passage. Urine usually emerges slowly, in drops instead of a stream, with dribbling afterward.
Lycopodium remedy may be helpful if urine is slow to emerge, with pressure felt in the prostate both during and after urination. The prostate is enlarged, and impotence may also be a problem. People who need this remedy often suffer from digestive problems with gas and bloating, and have an energy slump in the late afternoon.

Sabal serrulata. A frequent urge to urinate at night, with difficulty passing urine, and a feeling of coldness in the sexual organs, suggest a need for this remedy. It is sometimes also used in lower potencies for urinary incontinence in older men. This remedy is made from saw palmetto which is also used as an herbal extract for similar prostate problems.

Thuja. When the prostate is enlarged, and the person has a frequent urge to urinate, with cutting or burning pain felt near the bladder neck, this remedy may bring relief. After urine passes, a dribbling sensation may be felt. A forked or divided urine stream is sometimes seen when this remedy is needed.

\section{Lifestyle Counseling}

Some lifestyle preventive or management plans may include: limiting consumption of caffeine and alcohol, reducing liquid consumption for 2 hours and going to the toilet before sleep, long journeys, or other occasions when urinating may be difficult, emptying the bladder as thoroughly as possible with each urination, doing exercises to strengthen the pelvic floor muscles, eating more fiber to help prevent constipation, which can worsen symptoms of $\mathrm{BPH}$, avoiding medications that can make $\mathrm{BPH}$ symptoms worse, such as antihistamines and decongestants, reaching and maintaining a healthy weight, adopting a healthful, low-fat diet and limiting spicy foods and exercising regularly [44].

\section{Acupuncture}

According to McConnell et al., [45], acupuncture and Chinese herbal medicine are effective for the alleviation of urinary retention caused by benign prostatic hyperplasia (BPH). Studies also shown that stimulation of acupoints with electroacupuncture regulates micturition, specifically contraction of the bladder detrusor muscle and opening of the internal sphincter [46]. Modern studies also document that acupuncture eliminates congestion or edema and relieves urethral pressure [47].

\section{Challenges of naturopathic approach in managing BPH Side-Effects}

Accordoing to Xinrong et al., [48], electroacupuncture may have some few side effects including mild nausea, dizziness, feeling faint, or fainting, pain or light bleeding when the needle is inserted, redness or bruising at the needle site, infection at the needle site, though this is rare when single-use 
sterile needles are used. Some people have reported dizziness, headache, nausea, vomiting, constipation, impotence, and diarrhea after taking saw palmetto [49]. Furthermore, green tea can cause stomach upset and constipation. Green tea extracts have been reported to cause liver and kidney problems in rare cases [50]. It can cause side effects because of the caffeine. Thyroid problems such as hypothyroidism (too little thyroidhormone) or goiter: Babassu might decrease thyroid function [51]. This might make certain conditions, such as hypothyroidism or goiter, worse.

\section{Sociodemographic and Socioeconomic Challenges}

Male unemployment corresponds with a rise in stress and other mental health issues, including depression and anger making affordability a challenge. Financial crisis faced by unemployed men causes may them unable to afford the remedies [52]. Apparently, the location might also be problem in accessing some foods and other natural remedies. Accessibility and awareness of naturopathy might be a challenge that hinder patients [10].

\section{Profile of the Study Area AND Methodolody INTRODUCTION}

This chapter presents the sources and methods that were used in collecting data for the research. It deals specifically with the sampling procedure used in selecting a sample for the research, the instruments used for data collection and data analysis. It also provides a brief description of the study area.

\section{Profile of Adenta Municipal, population, location and size}

The Adenta Municipal is one of the districts in the Greater Accra Region of Ghana. Its capital is Adenta East. The district is among the new districts and municipalities created in 2008.

The district is bordered to the north by La Nkwantanang Madina Municipal District, to the east by Kpone Katamanso District and Tema Metropolis District, to the south by Ledzokuku-Krowor Municipal District, and to the west by Accra Metropolis District. The total area of the district is 92.84 square kilometers. According to the 2010 census, the population of the district is 78,215 with 39,366 males and 38,849 females. The current population based Ghana Statistical Service record is 96,478 .

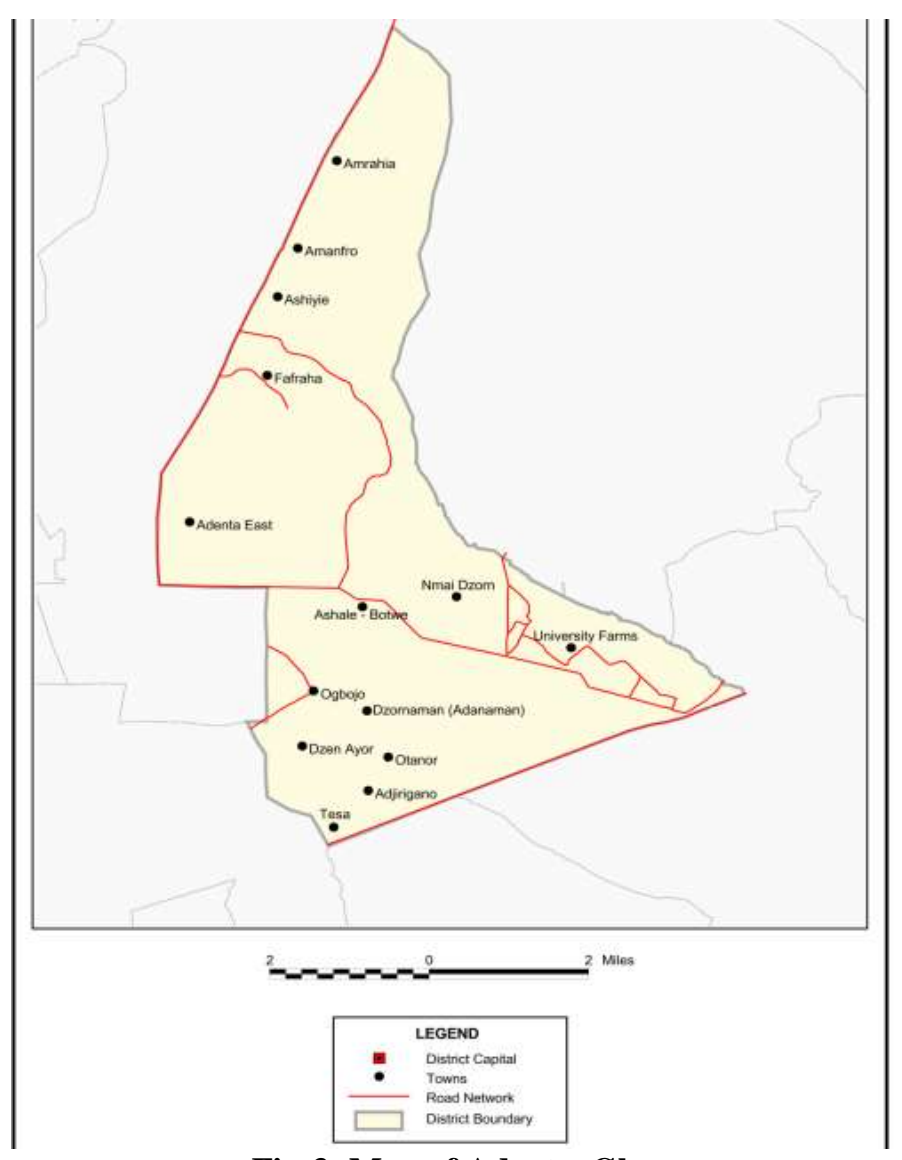

Fig-3: Map of Adenta, Ghana Source: GSS, 2010 


\section{Research Design}

The researcher adopted the descriptive cross sectional study design. According to Setia [53], crosssectional studies are used to assess the burden of health needs of a population and are particularly useful in informing the planning, monitoring, evaluation and allocation of health resources. Cross-sectional studies are relatively faster and inexpensive. Hence, the study used the cross-sectional survey aimed at describing the prevalence and associated risk factors of $\mathrm{BPH}$ and naturopathic practices in the Adenta Municipality.

\section{Sources of data}

Data for the study was obtained primarily from field work by the researcher. This was done through interviews. The following were the respondents interviewed by the researcher; men thirty years and above $(\geq 30)$ affected with benign prostatic hyperplasia (PSA> 4.0ng/ml) and are using naturopathic methods of management at the various naturopathic centers within the Adenta municipality. List of various registered naturopathic centers was obtained as a secondary data. Also data was obtained from the naturopathic centers.

\section{Study Population}

The population of interest is the study's target population that it intends to study [54]. The population of study included men thirty years and above $(\geq 30)$ affected with BPH and are using naturopathic methods of management at the various naturopathic centers within the Adenta municipality.

\section{Determination of sample size, sampling and sampling technique}

Sampling is the process of selecting or searching for situations, context and/or participants who provide rich data of the phenomenon of interest. It is an important tool for research studies because the population of interest usually consists of too many individuals for any research project to include as participants [55]. The research used a combination of purposive sampling (a type of non-probability sampling method), and simple random sampling (a type of probability sampling technique) sampling methods in selecting the sample units for investigations.

\section{The Study Adopted Purposive and Convenience Methods of Sampling}

According to Habib et al., [56], purposive sampling is a form of non-probability sampling where samples are chosen by intentionally seeking individuals or situations that meet criteria of interest or are likely to provide greater understanding of a chosen concept of research. Hence, the researcher used this method in selecting four (4) naturopathic centers in the municipality, Adenta.

Convenience sampling technique was used to recruit 30 patients visiting the naturopathic centers in the municipal. According to Etikan et al., [57], convenience sampling is a type of nonprobability sampling in which people are sampled simply because they are "convenient" sources of data for researcher. These patients were chosen because they agreed to take part of the research. Indications of an elevated total PSA, defined as $>4.0 \mathrm{ng} / \mathrm{ml}$ was used as an inclusion criterion.

\section{Data Collection Instruments}

The instrument use to collect data depend on the type of data. For the purposes of survey in this study, data was mainly obtained by use of questionnaires and interview guide.

\section{Questionnaires}

The questionnaire is a tool designed for collection of quantitative data by providing quick responses. This data collection tool allowed the researcher to develop series of structured questions and prompts for the purpose of gathering information from the respondents [58]. This tool assisted the study to gather information such as age, educational status, marital status and religion. Furthermore, various identified risk factors including smoking, family history of prostate cancer, number of sexual partners, alcohol, marriage duration, hypertension, diabetes, age of first sexual intercourse, heart attack as well as rheumatoid arthritis and patients' satisfactions with naturopathic care and challenges of the various methods.

Checking for misunderstandings, incomplete concept coverage, inconsistent interpretations, satisficing and context effects, Collins [59] relates that, it is important to pre-test research instruments. The questionnaire was pre-tested using $5 \%$ of its respondents. The researcher interpreted to the patients of erectile dysfunction in Twi and Ga Languages since these languages in the study area was not a barrier. The pretest was answered and returned to the researcher where accuracy and appropriateness was checked.

\section{Interviews}

Interviews are active interactions between two or more people leading to a negotiated contextual based result [60]. The research adopted different forms of interviews as semi-structured, unstructured, face-to-face verbal interactions

A set of questions, both open ended and closed ended, were developed based on the various themes that underpinned naturopathic care of benign prostatic hyperplasia, roles that each method was required to play in the BPH management.

Data collection procedure and ethical considerations Approval and an introductory letter for the study was obtained from the authorities of Holistic and Naturopathic Medicine, Dr. Nyarkotey College of Holistic Medicine to the units of the various naturopathic centers in the study area and was accepted. 
The study also ensured strict adherence to the following ethical standards during its data collection exercises:

1. The study respected the dignity and welfare of all its respondents.

2. Again, the study respected the freedom and rights of its respondents to decline

3. participating in it.

4. Additionally, the study ensured and maintained the confidentiality of all the data

5. it collected from its respondent.

6. Furthermore, the study guarded against violating or invading the privacy of all its

7. respondents.

8. The study anonymized the identity of its respondents (the study used code numbers instead of the names of its respondents to analyze their individual responses).

Most importantly, in keeping with Cooper \& Schindler [65] admonishment, the study was conducted in a manner that ensured that none of its respondents suffered any intentional harm, discomfort, mental anguish, embarrassment or loss of privacy.

\section{Methods of Data Analysis and Presentation}

Analysis of data is a process of editing, cleaning, transforming, and modeling data with the goal of highlighting useful information, suggestion, conclusions, and supporting decision making [61]. Data from the field was edited and coded appropriately to make meaning out of them. Editing was done to correct errors, check for nonresponses, accuracy and correct answers. Coding was done to facilitate data entering and a comprehensive analysis. Descriptive statistics was the medium used for analysis. The software was the Statistical Package for Social Science version twenty (SPSS 20). The study employed descriptive and inferential statistics to show the relationships between erectile dysfunction and its determinants, naturopathic methods and level of satisfaction, challenges and patronage by the subjects. This included percentages, mean and standard deviation, while inferential statistics was correlation analysis using chi-square (Pearson value, $\mathrm{p} \leq 0.05)$.

\section{Presentation of Survey ReSults INTRODUCTION}

This chapter presents the analysis and results of findings of the prevalence and risk factors of benign prostatic hyperplasia among men aged thirty and above in the Adenta municipality. These are obtained from the interviews conducted as well as other relevant documents such as documents obtained from the various naturopathic centers in the study area. They are discussed in sections that reflect the objectives of the study.

\section{Socio-Demographic and Economic Characteristics of the Respondents}

A total of fifty 30 men aged thirty and above with benign prostatic hyperplasia and had their prostatespecific antigen recorded (respondents) were recruited for the study. The results presented in the Table- 1 indicated that, half $(50 \%)$ of the respondents aged between 30 and 40 years, while the rest aged 41 years and above. Educationally, on a few $(33.3 \%)$ of the respondents was educated, $33.3 \%$ of the study's respondents were uneducated whilst another $33.3 \%$ had had attained tertiary education. Meanwhile half (50\%) the respondents were unemployed with less percentage $(20 \%)$ gainfully employed by the public sector. Also, greater proportion $(66.7 \%)$ of the respondents were not satisfied financially with their job status.

Table-1: Socio-demographic/economic characteristics of respondents

\begin{tabular}{|l|l|l|l|}
\hline Characteristic of respondent & & Frequency & Percentage (\%) \\
\hline Age & $30-40$ & 15 & 50 \\
\hline & $41-50$ & 5 & 16.7 \\
\hline & $51-60$ & 5 & 16.7 \\
\hline Educational level attained & $\geq 61$ & 5 & 16.7 \\
\hline & Uneducated & 10 & 33.3 \\
\hline & Primary/JSS/JHS/SHS & 10 & 33.3 \\
\hline Occupation & Tertiary & 10 & 33.3 \\
\hline & Public sector work (government) & 5 & 16.7 \\
\hline & Privately employed & 5 & 16.7 \\
\hline & Entrepreneur & 5 & 16.7 \\
\hline & Unemployed & 15 & 50 \\
\hline Are you satisfied financially with your job? & Other & 0 & 0 \\
\hline & Yes & 10 & 33.3 \\
\hline & Oother & 20 & 66.7 \\
\hline Total & & 0 & 0 \\
\hline
\end{tabular}

Source: Field survey, 2020 


\section{Risk Factors of Benign Hyperplasia among the Respondents}

On Table- 2 below, in order to assess the risk factors of $\mathrm{BPH}$, out of the 30 respondents, a greater proportion $(90 \%)$ of the respondents was ever diagnosed with hypertension, diabetes mellitus (83.3\%), hormonal disturbances (86.7\%), hypercholesterolemia $(83.3 \%)$, ever smoked $(60 \%)$, consumed alcohol (93.3\%). A higher number of the respondents 20(66.7) relied on red meat as their source of protein and more than half of the respondents had had family history of prostrate disturbances.

Table-2: Other risk factors of benign prostatic hyperplasia

\begin{tabular}{|c|c|c|c|}
\hline Characteristic & & Frequency & Percentage (\%) \\
\hline \multicolumn{4}{|l|}{$\begin{array}{l}\text { Have you been diagnosed } \\
\text { with: }\end{array}$} \\
\hline \multirow[t]{2}{*}{ Hypertension? } & Yes & 27 & 90 \\
\hline & No & 3 & 10 \\
\hline \multirow[t]{2}{*}{ Any cardiac disease? } & Yes & 15 & 50 \\
\hline & No & 15 & 50 \\
\hline \multirow[t]{2}{*}{ Stroke? } & Yes & 10 & 33.3 \\
\hline & No & 20 & 66.7 \\
\hline \multirow[t]{2}{*}{ Diabetes mellitus? } & Yes & 25 & 83.3 \\
\hline & No & 5 & 16.7 \\
\hline \multirow[t]{2}{*}{ Hormonal disturbances? } & Yes & 26 & 86.7 \\
\hline & No & 4 & 13.3 \\
\hline \multirow[t]{2}{*}{ Hypercholesterolemia? } & Yes & 25 & 83.3 \\
\hline & No & 5 & 16.7 \\
\hline \multirow{2}{*}{$\begin{array}{l}\text { Prostate } \\
\text { disturbance/surgery? }\end{array}$} & Yes & 10 & 33.3 \\
\hline & No & 20 & 66.7 \\
\hline \multirow[t]{2}{*}{ Smoked? } & Yes & 18 & 60 \\
\hline & No & 12 & 40 \\
\hline \multirow[t]{2}{*}{ Alcohol? } & Yes & 28 & 93.3 \\
\hline & No & 2 & 6.7 \\
\hline \multirow{4}{*}{$\begin{array}{l}\text { What is your main source } \\
\text { of protein? }\end{array}$} & Red meat & 20 & 66.7 \\
\hline & Lean meat/ fish & 5 & 16.7 \\
\hline & Vegetables & 5 & 16.7 \\
\hline & Others, & 0 & 0 \\
\hline \multirow[t]{2}{*}{$\begin{array}{l}\text { Family history prostate } \\
\text { problems }\end{array}$} & Yes & 20 & 66.7 \\
\hline & No & 10 & 33.3 \\
\hline Total & & 30 & 100 \\
\hline
\end{tabular}

Source: Field survey, 2020

\section{Diagnosis and symptoms of BPH experiences by the respondents}

As recorded in Table-3, all thus, 30(100\%) had their prostatic-specific antigen (PSA) tested and recorded in their cards (PSA $>4 \mathrm{ng} / \mathrm{mL}$ ). Out of the 30 respondents, a greater proportion of the respondents reported to have experienced urinary incontinence (66.7\%), swollen glands $(66.7 \%)$. All $(100 \%)$ the respondents had had painful urination with dribbling urinal stream and had to strain during urination. 
Table-3: Diagnosis and symptoms of BPH by the respondents

\begin{tabular}{|l|l|l|l|}
\hline Variable & & Frequency & Percentage \\
\hline Have you had your PSA tested? & Yes & 30 & 100 \\
\hline & No & 0 & 0 \\
\hline Report of PSA $(\mathrm{ng} / \mathrm{ml})$ & $<4$ & 0 & 0 \\
\hline & $>4$ & 30 & 100 \\
\hline Urinary Incontinence & Yes & 20 & 66.7 \\
\hline & No & 10 & 33.3 \\
\hline Blood in urine & Yes & 15 & 50 \\
\hline & No & 15 & 50 \\
\hline & & & \\
\hline Waist pain & Yes & 10 & 33.3 \\
\hline & No & 20 & 67.3 \\
\hline Swollen gland & Yes & 20 & 66.7 \\
\hline & No & 10 & 33.3 \\
\hline Pain upon Urinating & Yes & 30 & 100 \\
\hline & No & 0 & 0 \\
\hline Bleeding problems & Yes & 15 & 50 \\
\hline & No & 15 & 50 \\
\hline Straining & Yes & 30 & 100 \\
\hline & No & 0 & 0 \\
\hline Dribbling & Yes & 30 & 100 \\
\hline & No & 0 & 0 \\
\hline Change in urination & Yes & 20 & 66.7 \\
\hline & No & 10 & 33.3 \\
\hline Total & & 30 & 100 \\
\hline
\end{tabular}

Source: Field survey, 2020

\section{Naturopathic care of benign prostatic hyperplasia} among the respondents

From the Table-4 below, all $30(100 \%)$ the respondents were naturopathic approaches in managing their symptoms. All (100\%) the respondent adopted diet therapy and clinical nutrition, more than half (66.7\%) were using herbal medicine, a greater proportion $(83.3 \%)$ adhered to homeopathic and life style counselling approaches and more than half $(66.7 \%)$ of them were using chines traditional medicine and acupuncture.

Table-4: Naturopathic approaches used by respondents

\begin{tabular}{|l|l|l|l|}
\hline Variable & & Frequency & Percentage \\
\hline Naturopathic use & Yes & 30 & 100 \\
\hline & No & 0 & 0 \\
\hline Diet therapy and clinical nutrition & Yes & 30 & 10 \\
\hline & No & 0 & 0 \\
\hline Botanical medicine (Herbalism) & Yes & 20 & 66.7 \\
\hline & No & 10 & 33.3 \\
\hline Homeopathic Medicine & Yes & 25 & 83.3 \\
\hline & No & 5 & 16.7 \\
\hline Lifestyle counselling & Yes & 30 & 100 \\
\hline & No & 0 & 0 \\
\hline Traditional Chinese medicine / acupuncture & Yes & 20 & 66.7 \\
\hline & No & 10 & 33.3 \\
\hline Total & & $\mathbf{3 0}$ & $\mathbf{1 0 0}$ \\
\hline
\end{tabular}

Source: Field survey, 2020

\section{Benefits of Naturopathic Methods of Management}

From the Table-5 below, out of the 30 respondents, majority of the respondents were using the naturopathic methods of treatment for the reason that, it helped them reduced their symptoms of benign prostatic hyperplasia with less side-effects $(90 \%)$, it provided natural and healing therapies (100\%), it made them felt positive and hopeful for the future $(66.7 \%)$, they were looking for cure (83.3\%). Meanwhile, a greater proportion $(83.3 \%)$ of the respondents adhered to the naturopathic method of treatment not for the purpose of comfort from touch, talk and time with therapist. 
Table-5: Benefits of naturopathic approaches adhered by the respondents

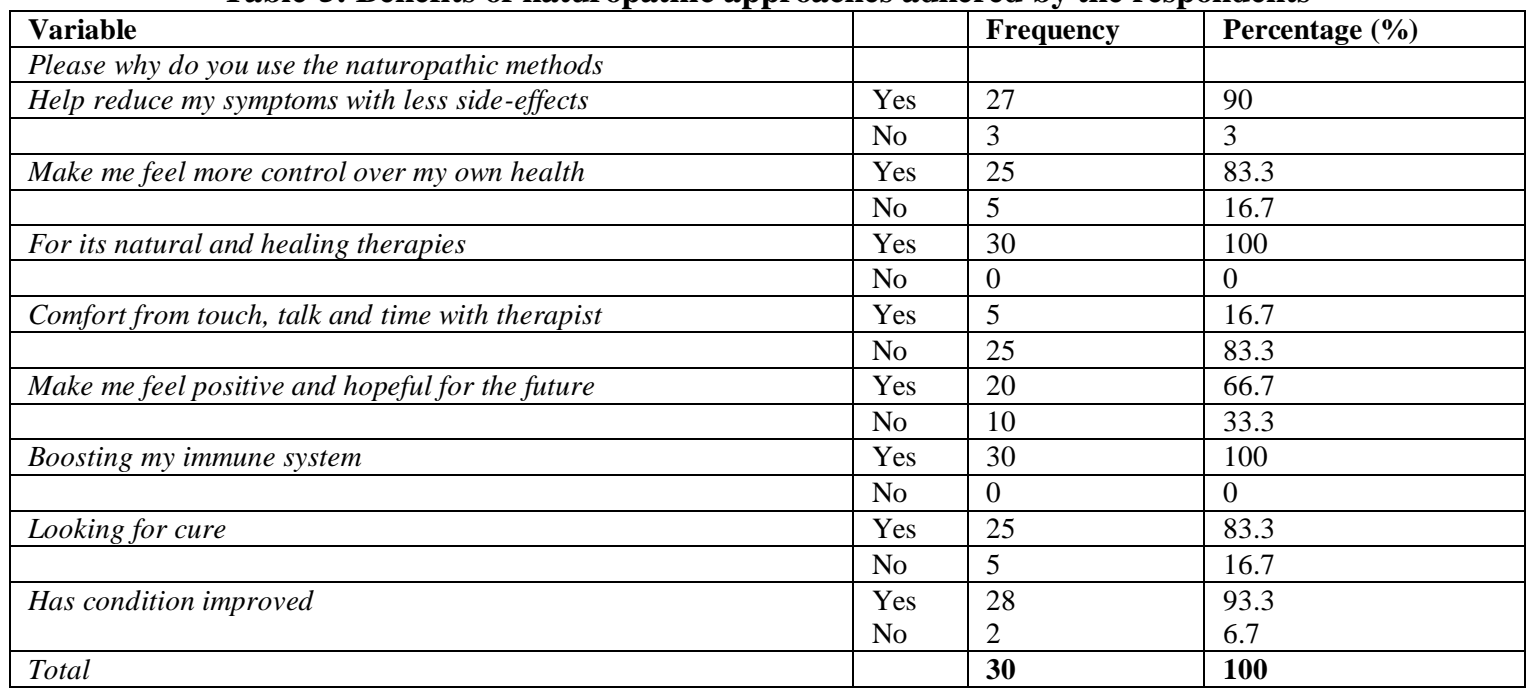

\section{Challenges in Using Naturopathic Methods}

From the Table- 6 below, out of the 30 respondents, a few of the respondents 10 (33.3\%) reported to have encountered challenges in the naturopathic methods. Out the 10 respondents with challenges, half $(50 \%)$ found it difficult affording the remedies, $70 \%$ experienced side-effects while a lesser percentage $(30 \%)$ of them reported to have not seen improvement in their condition. Among the 7 respondents with the side effects, majority $(71.4 \%)$ had had nausea, stomach upsets and vomiting with a few (28.6\%) experiencing skin rashes and itches.

Table-6: Challenges in using the naturopathic methods by the respondents

\begin{tabular}{|c|c|c|c|}
\hline Variable & & Frequency & Percentage $(\%)$ \\
\hline \multirow[t]{2}{*}{ Do you experienced challenges in using naturopathic methods? } & Yes & 10 & 33.3 \\
\hline & No & 20 & 66.7 \\
\hline Total & & 50 & 10 \\
\hline \multirow[t]{2}{*}{ Difficult affording the remedies } & Yes & 5 & 50 \\
\hline & No & 5 & 50 \\
\hline \multirow[t]{2}{*}{ Side effects } & Yes & 7 & 70 \\
\hline & No & 3 & 30 \\
\hline \multirow[t]{2}{*}{ Does not get healing/improvement } & Yes & 3 & 30 \\
\hline & No & 7 & 70 \\
\hline Other... & Yes & 0 & 0 \\
\hline Total & & 10 & 100 \\
\hline \multicolumn{4}{|l|}{ Side effects } \\
\hline \multirow{2}{*}{ Nausea, stomach upsets, vomiting } & Yes & 5 & 71.4 \\
\hline & No & 2 & 28.6 \\
\hline \multirow[t]{2}{*}{ Skin rashes, itches } & Yes & 2 & 28.6 \\
\hline & No & 5 & 71.4 \\
\hline Other, Specify & Yes & 0 & 0 \\
\hline Total & & 7 & 100 \\
\hline
\end{tabular}

\section{Prevalence and determinants of erectile dysfunction}

According to American Cancer Society guideline for the early detection of prostate cancer [21], a person with prostatic-specific hyperplasia (PSA> $4.0 \mathrm{ng} / \mathrm{ml}$ ) is said to have BPH. From the above definition the study used the recorded PSA from the various naturopathic centers and from the records, all $(100 \%)$ the respondents met the criteria and hence the overall prevalence.

The study therefore used the correlational chisquare analysis of PSA compared with other variables and the results is presented below.
Benign Prostatic Hyperplasia and Socio Demographic/Economic Determinants

From the Table-7 below, half $15(50 \%)$ of the respondents were within 30-40 age bracket. This age range was statistically ( $p$. value $=0.03$ ) while the other half covered age 41 and above, also the same Pearson value $(\mathrm{P}<0.05)$. Hence the different age ranges were associated with BPH. Educational status was not associated with benign prostatic hyperplasia (p. value $>0.05)$. Meanwhile financial satisfaction associated significantly with PSA level as respondents who were not financially stablished were more associated $(\mathrm{p}=0.01)$. 


\section{Benign Prostatic Hyperplasia and Risk Factors}

From Table-7 below, respondents who were ever diagnosed with hypertension, diabetes and hypercholesterolemia were strongly associated ( $\mathrm{p}$. value $<0.05)$ with BPH. Alcohol consumption and smoking were also related to high prostatic-specific antigen with ( $\mathrm{P}$ value of 0.0000 and 0.003 respectively). Others were, those who consumed red meat as main source of protein $(\mathrm{p}$. value $=0.000)$ and family history of prostrate disturbances $(\mathrm{P}<0.05$. Urinary incontinence, painful urination, dribble streams and swollen gland were associated with high PSA $(\mathrm{P}<0.05)$.
High Prostatic Antigen and Naturopathic Use

All the respondents adopted naturopathic method of treatment from Table-7 below. This was statistically significant with the condition, BPH with the chi-square, Pearson value of 0.0000. diet and clinical nutrition, botanical medicine, herbs and lifestyle counselling were the most utilized methods. The respondent encountered challenges but this was statistically insignificant $(\mathrm{P}=0$. 65). Meanwhile, majority of the respondents had their condition improved by using the naturopathic methods with statistically significant $\mathrm{P}$-value $<0.05$.

Table-7: Risk factors of benign prostatic hyperplasia and naturopathic use

\begin{tabular}{|c|c|c|}
\hline 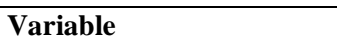 & PSA $>4 \mathrm{ng} / \mathrm{ml}$ & Test statistic \\
\hline$B P H$ & $30(100)$ & \\
\hline $\begin{array}{l}\text { Age range } \\
30-40 \\
\geq 41\end{array}$ & $\begin{array}{l}15(50) \\
15(50)\end{array}$ & $\begin{array}{l}* 0.003 \\
* 0.003\end{array}$ \\
\hline $\begin{array}{l}\text { Level of education } \\
\text { Educated } \\
\text { Uneducated }\end{array}$ & $\begin{array}{l}20(66.7) \\
10(33.3)\end{array}$ & $\begin{array}{l}0.35 \\
0.35\end{array}$ \\
\hline $\begin{array}{l}\text { Financial satisfaction } \\
\text { Yes } \\
\text { No }\end{array}$ & $\begin{array}{l}10(33.3) \\
20(66.7)\end{array}$ & $\begin{array}{l}0.07 \\
* 0.01\end{array}$ \\
\hline $\begin{array}{l}\text { Hypertension } \\
\text { Yes } \\
\text { No }\end{array}$ & $\begin{array}{l}27(90) \\
3(10)\end{array}$ & $\begin{array}{l}* 0.04 \\
0.34\end{array}$ \\
\hline $\begin{array}{l}\text { Diabetes } \\
\text { Yes } \\
\text { No }\end{array}$ & $\begin{array}{l}25(88.3) \\
5(16.7)\end{array}$ & $\begin{array}{l}* 0.03 \\
0.63\end{array}$ \\
\hline $\begin{array}{l}\text { Hypercholesterolemia } \\
\text { Yes } \\
\text { No }\end{array}$ & $\begin{array}{l}25(83.3) \\
10(16.7)\end{array}$ & $\begin{array}{l}* 0.0001 \\
0.56\end{array}$ \\
\hline $\begin{array}{l}\text { Alcohol } \\
\text { Yes } \\
\text { No }\end{array}$ & $\begin{array}{l}28(93.3) \\
2(6.7)\end{array}$ & $\begin{array}{l}* 0.0000 \\
0.45\end{array}$ \\
\hline $\begin{array}{l}\text { Red meat } \\
\text { Yes } \\
\text { No }\end{array}$ & $\begin{array}{l}20(66.7) \\
10(33.3)\end{array}$ & $\begin{array}{l}* 0.0000 \\
0.56\end{array}$ \\
\hline Smoking & $18(60)$ & $* 0.003$ \\
\hline $\begin{array}{l}\text { Family history } \\
\text { Yes } \\
\text { No }\end{array}$ & $\begin{array}{l}20(66.7) \\
10(33.3)\end{array}$ & $\begin{array}{l}* 0.002 \\
0.43\end{array}$ \\
\hline $\begin{array}{l}\text { Urinary incontinence } \\
\text { Yes } \\
\text { No }\end{array}$ & $\begin{array}{l}20(66.7) \\
10(33.3)\end{array}$ & $\begin{array}{l}* 0.02 \\
0.35\end{array}$ \\
\hline $\begin{array}{l}\text { Swollen gland } \\
\text { Yes } \\
\text { No }\end{array}$ & $\begin{array}{l}20(66.7) \\
10(33.3)\end{array}$ & $\begin{array}{l}* 0.02 \\
0.35\end{array}$ \\
\hline $\begin{array}{l}\text { Painful urination/dribbling } \\
\text { Yes } \\
\text { No }\end{array}$ & $\begin{array}{l}30(100) \\
0(0)\end{array}$ & $* 0.0000$ \\
\hline $\begin{array}{l}\text { Naturopathic use } \\
\text { Yes } \\
\text { No }\end{array}$ & $\begin{array}{l}30(100) \\
0(0)\end{array}$ & $* 0.000$ \\
\hline $\begin{array}{l}\text { Challenges of naturopathy } \\
\text { Yes } \\
\text { No }\end{array}$ & $\begin{array}{l}10(33.3) \\
20(66.7)\end{array}$ & 0.65 \\
\hline $\begin{array}{l}\text { Improved condition } \\
\text { Yes } \\
\text { No }\end{array}$ & $\begin{array}{l}28(93.3) \\
2(6.7)\end{array}$ & $* 0.0002$ \\
\hline
\end{tabular}

Source: Field survey, 2020 


\section{Discussion of Survey Results INTRODUCTION}

This chapter presents summary and discursion of key findings of the study. These findings are derived from the results from the field work. Recommendations from the study are highlighted to show how naturopathic practices in the area can be strengthen and sustained in the study area and Ghana as a whole.

\section{Socio-Demographic and Economic Risk Factors of Benign Prostatic Hyperplasia}

Benign prostatic hyperplasia is sometimes associated with age, educational status, economic stability and several other sociodemographic and health behavioral factors [62]. Respondents of all category age groups from thirty and above (>30years) were significantly associated with the condition. A study was done by Jeong et al., [63] to ascertain the association of metabolic syndrome and benign prostate enlargement in young Korean males revealed that, all age decades from 30 to 60 , prostate volumes were larger with statistical significance in the metabolic syndrome group than in the non-MS group. Moreover, there was significant association with age fifty and above. The finding is related to Roehrborn \& Rosen [24] who found that benign prostatic hyperplasia affects about 50 percent of men between the ages of 51 and 60 and up to 90 percent of men older than 80 . Uneducated, those who advance beyond primary and to tertiary was not statistically significant with high PSA $(\mathrm{p}=0.35)$. A research was done by Patel \& Parsons [28] and found negative correlation between $\mathrm{BPH}$ and the level of education of respondents. However, this contradicted with Bostanci et al., [64], who revealed that was a statistically significant correlation between $\mathrm{BPH}$ and educational level. Financial instability associated positively to $\mathrm{BPH}$ development maybe due to stress and anxieties. Roehrborn \& Rosen [24] also found strong correlation among respondents with anxiety, depression, insomnia, and those who were financially handicapped.

\section{Risk Factors of Benign Prostatic Hyperplasia}

Among the risk factor for $\mathrm{BPH}$ included hypertension, hypercholesterolemia, diabetes, family history of prostate disturbances, hormonal disturbances, alcohol and red meat consumption, and smoke $(\mathrm{P}<0.005)$. This related to Patel \& Parsons [28] who revealed that, strong relationship between family history of prostate problems or abnormalities with men testicles and their risk of BPH. Obese men with diabetes and/or high blood pressure for long durations are at an increased risk of BPH [30]. According to Hwang et al., [31], men with hypertension are more likely to have large prostate volume than men without hypertension. Abdollah et al., [32] also found positive correlation between hypercholesterolemia, red meat consumption and diabetes and the symptoms of BPH.
Benign prostatic hyperplasia and naturopathic use Naturopathic use was high among the respondents. Increased use of the approaches might have attributed to its benefits of improving their condition. Even though there were some forms of challenges with use of naturopathy, that was not significantly associated with high PSA as majority of the respondents saws improvement in their symptom with strong association of naturopathic use $(\mathrm{P}=0.000002)$. Among the naturopathic approaches used were diet and clinical nutrition, homeopathy, lifestyle counseling and botanical medicine. According to [10], naturopathic approaches to managing symptoms of benign prostatic hyperplasia includes herbs, homeopathy, exercise, and nutritional counseling.

\section{CONCLUSION AND RECOMMENDATION CONCLUSION}

All the respondents were having the problem of benign prostatic hyperplasia. This was partly due financial challenges, disease history such as arterial hypertension, diabetes, hormonal and prostate disturbances, increased cholesterol, red meat consumption and alcohol abuse and family history of prostate disturbances.

The respondents adopted the use of naturopathy and had their condition improved. Among the naturopathic approaches included: homeopathy, botanical; herbal, lifestyle counselling and diet and clinical nutrition. Even though the respondents encountered affordability and few side-effects, that did not prevent the them from adopting the naturopathic methods. Some of the respondents suggested that naturopathic practitioners minimized the prices of the various approaches and that they should create more awareness and sensitization programs to the public.

\section{RECOMMENDATION}

The study therefore suggested the following recommendation:

1. There is the need for naturopathic professionals to strengthen the level of education and awareness of naturopathic practices and remedies to the general public

2. Naturopathic practitioners should advance their research and education level in order to get more knowledge about benign prostatic hyperplasia and its treatment plan.

3. Further researches should be done by naturopathic research institutions in Ghana to evaluate the various naturopathic methods to improve upon its practice. It is also important for similar studies be carried out across the entire country to confirm the present study.

\section{DeClaration}

I hereby declare that this submission is my own work towards the diploma. And that to the best of 
my knowledge it contains neither materials previously published by another person or materials that have been accepted for the award of any other Diploma by the University or any other University except due acknowledgment has been made in the text.

\section{ACKNOWLEDGEMENT}

I am very grateful to the Almighty God for protecting and providing me with knowledge and guidance through this project. My special thanks goes to my supervisor and college president, Professor Raphael Nyarkotey Obu for his patience towards us during our being through this college and perfect editing of this work and the college administrator Mr. Amewugah George.

And to my husband Mr. Stephen Kofi Atakili who has been the back bone of my successful passing out from this college, my entire family and church leaders.

Also, to Mr. Yusif Abubakari, Mr. Gabriel Accam, Mr. Enchile and my colleague students their support. God bless you all abundantly for your good will.

\section{REFERENCES}

1. Parsons, J. K., Sarma, A. V., McVary, K., \& Wei, J. T. (2009). Obesity and benign prostatic hyperplasia: clinical connections, emerging etiological paradigms and future directions. The Journal of urology, 182(6S), S27-S31.

2. Lim, K. B. (2017). Epidemiology of clinical benign prostatic hyperplasia. Asian journal of urology, 4(3), 148-151.

3. Obu, R. (2014). The impact of complementary Therapies in Ghanaian Men diagnosed with Prostate Cancer: A critical review of the impact of complementary therapies in Ghanaian men diagnosed with Prostate cancer as part of the Psychology of cancer care.

4. Davidian, M. H. (2016). Guidelines for the treatment of benign prostatic hyperplasia. US Pharm, 41(8), 36-40.

5. Mante, O. D., Dayton, D. C., Carpenter, J. R., Wang, K., \& Peters, J. E. (2018). Pilot-scale catalytic fast pyrolysis of loblolly pine over $\gamma$ A12O3 catalyst. Fuel, 214, 569-579.

6. Zeff, J. L., Pamela Snider, N. D., \& Myers, S. P. (2006). A hierarchy of healing: the therapeutic order. medical education, 3, 15.

7. Jonler, M., Riehmann, M., Brinkmann, R., \& Bruskewitz, R. C. (1994). Benign prostatic hyperplasia. Endocrinology and metabolism clinics of North America, 23(4), 795-807.

8. Lepor, H. (2007). Alpha blockers for the treatment of benign prostatic hyperplasia. Reviews in urology, 9(4), 181.
9. Russo, A., La Croce, G., Capogrosso, P., Ventimiglia, E., Colicchia, M., Serino, A., ... \& Salonia, A. (2014). Latest pharmacotherapy options for benign prostatic hyperplasia. Expert opinion on pharmacotherapy, 15(16), 2319-2328.

10. Hechtman, L. (2018). Clinical naturopathic medicine. Elsevier Health Sciences.

11. Louise, C., Daniel Seitz, J. D., JoAnn Yanez, N. D., Paul Mittman, N. D., Michael Traub, N. D., Marcia Prenguber, N. D., ... \& DHANP, F. (2017). Naturopathic Medicine. Clinicians' and Educators' Desk Reference on the Integrative Health and Medicine Professions, 123.

12. Pizzorno, J. E., Murray, M. T., \& Joiner-Bey, H. (2016). The Clinician's Handbook of Natural Medicine E-Book. Elsevier Health Sciences.

13. Pagán, J. A., \& Pauly, M. V. (2005). Access to conventional medical care and the use of complementary and alternative medicine. Health Affairs, 24(1), 255-262.

14. Kirby, J. N., Tellegen, C. L., \& Steindl, S. R. (2017). A meta-analysis of compassion-based interventions: Current state of knowledge and future directions. Behavior Therapy, 48(6), 778792.

15. Arthur, N. (2005). Building from diversity to social justice competencies in international standards for career development practitioners. International Journal for Educational and Vocational Guidance, 5(2), 137148 .

16. McClure, M. W. (2002). An overview of holistic medicine and complementary and alternative medicine for the prevention and treatment of $\mathrm{BPH}$, prostatitis, and prostate cancer. World journal of urology, 20(5), 273-284.

17. Price, J. H., \& Murnan, J. (2004). Research limitations and the necessity of reporting them. American Journal of Health Education, 35(2), 66.

18. Pradidarcheep, W., Wallner, C., Dabhoiwala, N. F., \& Lamers, W. H. (2011). Anatomy and histology of the lower urinary tract. In Urinary Tract (pp. 117-148). Springer, Berlin, Heidelberg.

19. Aumüller, G. (2012). Prostate gland and seminal vesicles. Springer Science \& Business Media.

20. Calogero, A. E., Burgio, G., Condorelli, R. A., Cannarella, R., \& La Vignera, S. (2019). Epidemiology and risk factors of lower urinary tract symptoms/benign prostatic hyperplasia and erectile dysfunction. The Aging Male, 22(1), 1219.

21. Wolf, A. M., Wender, R. C., Etzioni, R. B., Thompson, I. M., D'Amico, A. V., Volk, R. J., ... \& DeSantis, C. (2010). American Cancer Society guideline for the early detection of prostate cancer: update 2010. CA: a cancer journal for clinicians, 60(2), 70-98.

22. Dicker, R. C., Coronado, F., Koo, D., \& Parrish, R. G. (2006). Principles of epidemiology in public 
health practice; an introduction to applied epidemiology and biostatistics.

23. Lopez, A. D., Mathers, C. D., Ezzati, M., Jamison, D. T., \& Murray, C. J. (Eds.). (2006). Global burden of disease and risk factors. The World Bank.

24. Roehrborn, C. G., \& Rosen, R. C. (2008). Medical therapy options for aging men with benign prostatic hyperplasia: focus on alfuzosin $10 \mathrm{mg}$ once daily. Clinical interventions in aging, 3(3), 511.

25. Grossfeld, G. D., \& Coakley, F. V. (2000). Benign prostatic hyperplasia: clinical overview and value of diagnostic imaging. Radiologic Clinics of North America, 38(1), 31-47.

26. Wilson, K. M., Kasperzyk, J. L., Rider, J. R., Kenfield, S., van Dam, R. M., Stampfer, M. J., ... \& Mucci, L. A. (2011). Coffee consumption and prostate cancer risk and progression in the Health Professionals Follow-up Study. Journal of the National Cancer institute, 103(11), 876-884.

27. Xu, H., Fu, S., Chen, Y., Chen, Q., Gu, M., \& Wang, Z. (2016). Smoking habits and benign prostatic hyperplasia: A systematic review and meta-analysis of observational studies. Medicine, 95(32).

28. Patel, N. D., \& Parsons, J. K. (2014). Epidemiology and etiology of benign prostatic hyperplasia and bladder outlet obstruction. Indian journal of urology: IJU: journal of the Urological Society of India, 30(2), 170.

29. Sanda, M. G., Beaty, T. H., Stutzman, R. E., Childs, B., \& Walsh, P. C. (1994). Genetic susceptibility of benign prostatic hyperplasia. The Journal of urology, 152(1), 115-119.

30. Ozden, C., Ozdal, O. L., Urgancioglu, G., Koyuncu, H., Gokkaya, S., \& Memis, A. (2007). The correlation between metabolic syndrome and prostatic growth in patients with benign prostatic hyperplasia. European urology, 51(1), 199-206.

31. Hwang, E. C., KIM, S. O., NAM, D. H., Yu, H. S., Hwang, I., Jung, S. I., ... \& Kim, G. S. (2015). Men with hypertension are more likely to have severe lower urinary tract symptoms and large prostate volume. LUTS: Lower Urinary Tract Symptoms, 7(1), 32-36.

32. Abdollah, F., Briganti, A., Suardi, N., Castiglione, F., Gallina, A., Capitanio, U., \& Montorsi, F. (2011). Metabolic syndrome and benign prostatic hyperplasia: evidence of a potential relationship, hypothesized etiology, and prevention. Korean journal of urology, 52(8), 507-516.

33. Dreikorn, K. (2002). The role of phytotherapy in treating lower urinary tract symptoms and benign prostatic hyperplasia. World journal of urology, 19(6), 426-435.

34. Pagano, E., Laudato, M., Griffo, M., \& Capasso, R. (2014). Phytotherapy of benign prostatic hyperplasia. A minireview. Phytotherapy research, 28(7), 949-955.
35. Goodarzi, D., Cyrus, A., Baghinia, M. R., Kazemifar, A. M., \& Shirincar, M. (2013). The efficacy of zinc for treatment of chronic prostatitis. Acta Med Indones, 45(4), 259-64.

36. Syed, D. N., Suh, Y., Afaq, F., \& Mukhtar, H. (2008). Dietary agents for chemoprevention of prostate cancer. Cancer letters, 265(2), 167-176.

37. Ranjan, P., Dalela, D., \& Sankhwar, S. N. (2006). Diet and benign prostatic hyperplasia: implications for prevention. Urology, 68(3), 470476.

38. Gerber, G. S. (2002). Phytotherapy for benign prostatic hyperplasia. Current urology reports, 3(4), 285-291.

39. Wagenlehner, F. M., Schneider, H., Ludwig, M., Schnitker, J., Brähler, E., \& Weidner, W. (2009). A pollen extract (Cernilton) in patients with inflammatory chronic prostatitis-chronic pelvic pain syndrome: a multicentre, randomised, prospective, double-blind, placebo-controlled phase 3 study. European urology, 56(3), 544-551.

40. Shrivastava, A., \& Gupta, V. B. (2012). Various treatment options for benign prostatic hyperplasia: A current update. Journal of mid-life health, 3(1), 10.

41. Shoskes, D. A., \& Manickam, K. (2003). Herbal and complementary medicine in chronic prostatitis. World Journal of Urology, 21(2), 109113.

42. Yarnell, E., \& Abascal, K. (2014). Western Use of Chinese Herbs for Common Urologic Conditions. Alternative and Complementary Therapies, 20(4), 183-190.

43. Weinstein, C. (2008). Benign Prostatic Hypertrophy: Analysis and Homeopathic treatment. American Journal of Homeopathic Medicine, 101(3).

44. Moyad, M. A., \& Lowe, F. C. (2008). Educating patients about lifestyle modifications for prostate health. The American journal of medicine, 121(8), S34-S42.

45. McConnell, J. D., Roehrborn, C. G., Bautista, O. M., Andriole Jr, G. L., Dixon, C. M., Kusek, J. W., ... \& Crawford, E. D. (2003). The long-term effect of doxazosin, finasteride, and combination therapy on the clinical progression of benign prostatic hyperplasia. New England Journal of Medicine, 349(25), 2387-2398.

46. Scaglia, M., Tullio, M., Destefano, I., \& Hultén, L. (2015). Acupuncture for Pelvic Floor Disorders. In Electrical Stimulation for Pelvic Floor Disorders (pp. 75-88). Springer, Cham.

47. Chang, S. (2013). The meridian system and mechanism of acupuncture: a comparative review. Part 3: mechanisms of acupuncture therapies. Taiwanese Journal of Obstetrics and Gynecology, 52(2), 171-184.

48. Xinrong, Y., Anmin, C., Fang, S., Bingyi, F., Jinlin, Q., Yingfu, M., ... \& Zhemin, G. (Eds.). (2003). Encyclopedic reference of traditional 
Chinese medicine. Springer Science \& Business Media.

49. Avins, A. L., Bent, S., Staccone, S., Badua, E., Padula, A., Goldberg, H., ... \& Kane, C. (2008). A detailed safety assessment of a saw palmetto extract. Complementary therapies in medicine, 16(3), 147-154.

50. Ravikumar, R., Sabin, C., Hilal, M. A., Bramhall, S., White, S., Wigmore, S., ... \& UK Vascular Resection in Pancreatic Cancer Study Group. (2014). Portal vein resection in borderline resectable pancreatic cancer: a United Kingdom multicenter study. Journal of the American College of Surgeons, 218(3), 401-411.

51. Vidovix, T. B., Januário, E. F. D., Bergamasco, R., \& Vieira, A. M. S. (2019). Bisfenol A adsorption using a low-cost adsorbent prepared from residues of babassu coconut peels. Environmental Technology, 1-13.

52. du Toit, M., de Witte, H., Rothmann, S., \& van den Broeck, A. (2018). Contextual factors and the experience of unemployment: A review of qualitative studies. South African Journal of Economic and Management Sciences, 21(1), 1-11.

53. Setia, M. S. (2016). Methodology series module 5: Sampling strategies. Indian Journal of Dermatology, 61(5), 505.

54. Majid, A., Roberts, S. G., Cilissen, L., Emmorey, K., Nicodemus, B., O’grady, L., ... \& Shayan, S. (2018). Differential coding of perception in the world's languages. Proceedings of the National Academy of Sciences, 115(45), 11369-11376.

55. Moser, A., \& Korstjens, I. (2018). Series: Practical guidance to qualitative research. Part 3: Sampling, data collection and analysis. European Journal of General Practice, 24(1), 9-18.

56. Habib, N. (2014). Some Oklahoma teachers leaving the state, profession. Tulsa World.
57. Etikan, I., Musa, S. A., \& Alkassim, R. S. (2016). Comparison of convenience sampling and purposive sampling. American journal of theoretical and applied statistics, 5(1), 1-4.

58. Dörnyei, Z., \& Taguchi, T. (2009). Questionnaires in second language research: Construction, administration, and processing. Routledge.

59. Collins, C. J., \& Clark, K. D. (2003). Strategic human resource practices, top management team social networks, and firm performance: The role of human resource practices in creating organizational competitive advantage. Academy of management Journal, 46(6), 740-751.

60. Roulston, K., \& Choi, M. (2018). Qualitative interviews. The SAGE handbook of qualitative data collection, 233-249.

61. Adèr, H. J., \& Mellenbergh, G. J. (Eds.). (2008). Advising on research methods. Proceedings of the 2007 KNAW colloquium. Johannes van Kessel Publ.

62. Messerer, M., Johansson, S. E., \& Wolk, A. (2001). Sociodemographic and health behaviour factors among dietary supplement and natural remedy users. European Journal of Clinical Nutrition, 55(12), 1104-1110.

63. Jeong, J. H., Kim, E. T., \& Kim, D. K. (2011). Association of metabolic syndrome and benign prostate enlargement in young Korean males. Korean Journal of Urology, 52(11), 757762.

64. Bostanci, Y., Kazzazi, A., Momtahen, S., Laze, J., \& Djavan, B. (2013). Correlation between benign prostatic hyperplasia and inflammation. Current opinion in urology, 23(1), 5-10.

65. Cooper, D. R., \& Schindler, P. S. (2001). Business Research Methods Boston: McGrawHiIIln'in. 